H. C., Ann. N.Y. Acad. Sci., Monograph on Autoimmunity, 1965, in press.

K., Fed. Proc., 1964, 23, 341.

van der Geld, H., Strauss, A. J. L., Kemp P. G., jun., and Exum, E. D., ibid., 1964, 23, 342 .

Osserman, K. E., and Weiner, L. B., Ann. N.Y Acad. Sci., Monograph on Autoimmunity, 1965 in press.

Strauss, A. J. L., van der Geld, H., Smith, C. W., McFarlin, D. E., Barlow, M., Cage, G. W., Ann. N.Y. Acad. Sci., Cont

12 McFarlin, D. E., Engel, W. K., and Strauss, A. J. L., ibid., 1965, in press.

13 Grob, D., Himei, H., and Namba, T., f. clin. Invest., $1964,43,1273$.

\section{The Nature of Cancer}

SIR,-In mongolism the accidental chromosomal change seems undoubtedly the cause of the condition. In chronic leukaemia chromosomal changes may occur in the leukaemic cells. Are these changes the result of the leukaemic process or are they the cause of it ? The appearance of chromosomal and mitotic changes in the cells of "cancer-insitu " (16 January, p. 154) suggest that these changes (whatever produces them) cause the cells in which they occur to behave riotously, producing a situation for which the body as a whole has no mechanism for its co-ordination.

As all malignant cells behave essentially in the same way-are invasive, produce metastases, lead a successful parasitic life-the process at work is obviously the same in all. Such process must surely be based on a normal one. During the individual's development the only time when a change occurs in the chromosomal arrangement is when certain panpotential cells no longer throw off soma cells but undergo reducing divisions to form gametes. What are the factors that operate to cause this sudden change after many divisions of somatic type with the full complement of chromosomes? Is it age ? Is it propinquity to certain somatic arrangements ? Is is due to a hormone produced elsewhere ? Do several factors operate? No one would suggest it is a virus. Is not the malignant process basically the same but uncoordinated, inchoate, and useless? The altered chromosomes produce cultures of parasitic cells which have no place in the victim's ontogeny. If we could find out what produces the sudden normal change to form gametes instead of soma cells, we may find that the same factors cause an old soma cell to become malignant by altering its chromosomes. The fertilized ova produces panpotential cells capable of giving rise to soma cells and gametes. The soma cells sacrifice their capacity to form sex cells in order to produce a body to protect and nourish the line of sex cells. There is every reason to suppose that in the somatic cells this capacity to form sex cells is only inhibited, not abolished. When after many generations a line of cells is growing old, when it is existing under conditions of stress and is receiving oft-repeated chemical or mechanical insults, when even it may be handicapped by acquiring a virus, the time may come when the hitherto dominant somatic side of the cell wanes and the suppressed gametoid side attempts to express itself by changes in the chromosomes and their arrangement. The result is not the production of a normal sex organ but a culture of parasitic invasive cells.

One may sum up by saying that the cancerous process is an attempt, by groups of

cells about to perish after a long life and many insults, to prevent extinction by doing the best they can to prepare for the production of gametes. The result is a disorderly invasive tissue, not under control because not provided for in ontogeny.

Surely this view, the perversion of a normal process, is more likely to be correct than the theory that malignancy is due to a chance mutation in somatic cells. In any case why should the chance mutation always bring about the same result ?

One is apt to be enamoured of one's own views, but I trust, if my theory is unreasonable or untenable, someone with as much right to criticize it as I have to propound it will state the grounds of objection. I taught it for many years and may have been wrong. Under the title "Gametoid Theory of Cancer," I contributed a letter to the Lancet ${ }^{1}$ outlining my theory in more detail and giving earlier references to it. I hope this will be consulted. It was written before the importance of the chromosomal changes in the very beginning of the malignant change was recognized.-I am, etc.,

University of Adelaide, John B. Cleland. Adelaide, South Australia.

\section{REFERENCE}

1 Cleland, J. B., Lancet, 1959, 1, 836.

\section{Treatment of Cystinuria}

SIR,-We were interested to hear Dr. $M$ Lotz and Dr. F. C. Bartter's comments (27 March, p. 855) on our paper (13 February, p. 403). We look forward to hearing more details of their work on cystinuria from their papers still in press. We must admit that we have not used low methionine diets at all in the routine treatment of cystinuria. The reason for this is that in our earlier paper we studied low protein intake as a means of lowering methionine intake and found that it did not make much difference to the cystine output, unless it was so low as to produce negative nitrogen balance. We have not been convinced by the literature so far which has claimed more success than we have had with low methionine diets. Recently in the treatment of homocystinuria we have had some experience with more specific low methionine diets in which total nitrogen intake was comparatively normal. These diets are an infernal nuisance to prepare and take, and while well justified in a serious condition such as homocystinuria ${ }^{2}$ they are hardly applicable as lifelong treatment in cystinuria with it relatively benign metabolic defect. Furthermore, there are theoretical arguments which suggest that depleting the dietary intake of methionine in a disease already causing grossly excessive loss of cystine could eventually produce an amino-acid deficiency. We look forward to hearing about the results of an actual therapeutic trial, especially if they are contrary to what we have been expecting. -We are, etc.

C. E. Dent.

M. FRIEDMAN

H. GrEen.

L. C. A. Watson.

University College Hospital Medical School

\section{REFERENCES}

1 Dent, C. E., and Senior, B., Brit. 7. Urol., 1955, 27, 317. arson, N. A. J., Dent, C. E., Field, C. M. B. B.
and Gaull, G. E., J. Pediat., 1965, 66, 565.

\section{Medical Orthopaedics}

SIR,- "Training in ophthalmology is largely surgical. Yet a large number of patients who consult ophthalmologists suffer from conditions which cannot be relieved by operation and are frequently ill-understood. ... . Consequently there has been a move by ophthalmologists in the last few years to establish medical ophthalmology clinics staffed jointly with physicians." I quote from the B.M.F. (10 April, p. 942).

Were the word " orthopaedics" substituted for "ophthalmology," the situation would be equally well described. Most musculoarticular disorders pose problems that are not amenable to surgery; yet the orthopaedic surgeon sees innumerable cases of, for example, backache, painful shoulder, or sprained knee, although the remedy is seldom an operation. Few would be sorry to refer such cases to a medical colleague, if one existed, with a primary interest in such diseases.

For this reason I have for many years recommended that the orthopaedic team should include an orthopaedic physician. In fact this concept has now been accepted at St. Thomas's Hospital, where earlier this year an orthopaedic physician was appointed.

This appears to me a move that should be as widely acknowledged as the ophthalmologists'; for it is unreasonable to expect promising young men to come for a grounding in orthopaedic medicine when they and I know that there are, as yet, no posts of this sort for them to go to on leaving their teaching hospital.-I am, etc.,

London W.1.

JAMES CyRIAX.

\section{Oral Contraception and Carcinoma}

SIR,_ "The pill" has been used as a contraceptive for many years now and yet, in spite of the many fears, there has been no corroborative evidence that it causes genital cancer. It is here suggested that its principal ingredient-namely, progesterone (progestogen)_-does not cause cancer, but indeed confers protection. We might therefore consider this as a "bonus" from "the pill."

It is well known that the prolonged action of oestrogen alone-for example, the patient over 40 years of age who is not ovulatingon the endometrium causes hyperplasia and cystic changes, and it is this rapid multiplication and proliferation of the cells which has been described as a possible precursor of endometrial carcinoma.

A woman taking " the pill" regularly is " injecting" into her circulation a synergistic combination of oestrogen and progesterone (=physiology). Therefore, instead of ever having a hyperplastic endometrium she will always tend to have a premenstrual-type endometrium with glandular and secretory changes. However, if a woman has already developed a thick endometrial hyperplasia it is possible to return this to the normal secretory phase by her taking a regular cyclical course of progesterone-e.g., " the pill." It is interesting to consider the well-known fact that the infertile woman (or the woman of low fertility) is more likely to develop endometrial carcinoma than the woman who has a large family. Possibly the former's reduced infertility was due to infrequent ovulation, 